\title{
APPLICABILITY OF MULTI-CRITERIA ANALYSIS METHODS FOR THE CHOICE OF MATERIAL AND TECHNOLOGY SOLUTIONS IN BUILDING STRUCTURES
}

\author{
Elïbieta Szafranko
}

Preliminary communication

The choice of material, structural and technology solutions is one of the key decisions to be made at the stage of planning and design of building projects The variety of structural elements and their potential for use result in a great number of factors influencing the choice of a specific solution. Taking a decision directly can be difficult, and it often requires the support of mathematical methods. This paper presents a fragment of a multi-criteria analysis of two alternative structural solutions of a roof girder. The applicability of the Indicator Method is presented, and the procedure and results obtained with the known MCE method are compared.

Keywords: material solutions; methodology; multi-criteria analysis

\section{Mogućnost primjene metoda analize s više kriterija u izboru materijala i tehnoloških rješenja u građevinskim konstrukcijama}

Izbor materijala, konstrukcijskih i tehnoloških rješenja, jedna je od ključnih odluka u stadiju planiranja i konstruiranja građevinskih projekata. Raznolikost konstrukcijskih elemenata i mogućnost njihove primjene rezultiraju velikim brojem čimbenika koji utječu na izbor određenog rješenja. Direktno donošenje odluke može biti teško i često zahtijeva podršku matematičkih metoda. U radu se predstavlja dio više-kriterijske analize dvaju alternativnih konstrukcijskih rješenja krovne grede. Predstavljena je primjenljivost Metode Indikator i uspoređeni su postupak i rezultati dobiveni poznatom MCE metodom.

Ključne riječi: analiza s više kriterija; metodologija; rješenja o materijalu

\section{Introduction}

Structural components of building structures can be made of various materials, using different structural solutions and technologies. They can be formed to any shape, but they have to conform to the valid legislation and provisions of construction law. These include: Eurocodes, standards, construction and technical regulations, health and safety rules, fire protection rules, and numerous technical and construction studies, expert studies and administrative decisions [1].

One of the basic requirements is to ensure the stability, strength, rigidity and durability of a building. This is ensured by the components of the building structure [2, 3]. Components of buildings have specified structural, functional and aesthetic roles. As already mentioned, depending on the functions, they can be made of various materials and have different shapes. The support structure comprises a number of components forming separate and solid units. The most common are bar components in the form of beams. They are applied in the construction of building roofs with considerable spans.

A distinct feature of the beams is their considerable length, multiple times greater than the cross-sectional size, and the most common loading pattern perpendicular to the beam's centreline. Examples include: girders, purlins, floor beams and joists. They are known as wooden, laminated, steel, reinforced concrete, prestressed reinforced concrete or cable concrete girders. The choice of one of these solutions can be difficult, and the final decision is not always the best possible one [1, 4].

Making such a decision can be aided by mathematics, offering a choice of methods. Those deserving particular attention are the multi-criteria analysis methods in which a number of factors can be taken into account. For various criteria affecting the ultimate decision they can prove to be useful and effective. An analysis of the choice of a structural element will be presented using the example of a roof girder.

\section{Description of solution variants}

While choosing an optimum girder solution, technical, aesthetic and economic criteria have to be taken into account. In the presented example two variants will be analysed: a pre-stressed concrete girder and a steel girder. Because of the technical and structural nature and production of pre-stressed girders by specialised prefabrication companies, they are among the solutions offering greatest resistance to ambient conditions. They are, however, relatively not very widespread. The prestressed components have numerous advantages and drawbacks. They are listed in Tab. 1. The application of a pre-stressed concrete solution also has economic benefits. The use of steel in $\mathrm{kg} / \mathrm{m}^{3}$ of concrete is three times less in the production of pre-stressed components than in the case of reinforced concrete components, yet compared to other solutions it is a costly structure.

The other solution analysed is the steel girder. The basic characteristics of this solution are listed in Tab. 2 . Steel structures, compared to those made of other materials, i.e. timber or reinforced concrete demonstrate highly uniform mechanical and physical properties. Steel as a construction material is characterised by uniform and high compression, and tensile strength. Both, the advantages and drawbacks of the solutions presented can be decisive for the choice of a specific solution. They cannot be clearly assessed. In some cases, the decision may depend on the ease of transport or installation time. Other factors may include the resistance to aggressive environments. Another critical factor can be the cost of project completion and the cost of maintenance later on. Nevertheless, a single feature of the solution considered should never affect the choice. 
Table 1 Advantages and drawbacks of a pre-stressed concrete girder

\begin{tabular}{|l|l|}
\hline \multicolumn{1}{|c|}{ Advantages } & \multicolumn{1}{|c|}{ Pre-stressed concrete girders } \\
\hline - high resistance to fire & - high production cost \\
\hline $\begin{array}{l}\text { - resistance to increased humidity and chemically aggressive } \\
\text { environments }\end{array}$ & - less widespread due to advanced execution technologies \\
\hline - high load bearing capacity & $\begin{array}{l}\text { - improvement of the quality required due to supervision required } \\
\text { at every production stage }\end{array}$ \\
\hline - resistance to dynamic loads & $\begin{array}{l}\text { - specialised machinery and mechanical equipment required for } \\
\text { production }\end{array}$ \\
\hline - reduced reinforcement cost & - high cost of launching the production of new components \\
\hline - very sleek components & - heavy equipment required for installation \\
\hline - modularity and standardisation & - costly transport \\
\hline - low deflection & - high structure weight \\
\hline
\end{tabular}

Table 2 Advantages and drawbacks of a steel girder

\begin{tabular}{|l|l|}
\hline \multicolumn{1}{|c|}{ Advantages } & \multicolumn{1}{|c|}{ Steel girders } \\
\hline $\begin{array}{l}\text { - lightweight structure resulting from a good weight to bearing } \\
\text { capacity ratio of components }\end{array}$ & - adverse effects of high temperature on the strength properties \\
\hline - easy transport of components & - susceptibility to corrosion \\
\hline - fast installation and removal regardless of weather conditions & $\begin{array}{l}\text { - low resistance to ambient conditions and aggressive } \\
\text { environments }\end{array}$ \\
\hline - fully recyclable material & - sensitivity to dynamic loads \\
\hline $\begin{array}{l}\text { - easy joining and installation of components at the construction } \\
\text { site }\end{array}$ & - great number of joints requiring precision during assembly \\
\hline - uniform mechanical and physical properties & \\
\hline - possibility of structure reinforcement & \\
\hline - fast structure assembly & \\
\hline - high workability and easy to join & \\
\hline
\end{tabular}

\section{Procedure}

In order to choose and consider a number of features and factors describing the solution analysed, it is recommended to apply one of the multi-criteria analysis methods $[5,6,7]$. While choosing a method to aid the decision-making process, attention should be drawn to such qualities as the legibility, quality and traceability of the results obtained, and the mathematical apparatus applied $[8,9,10]$. Also, the subjectivity of assessments is worth attention, since a number of methods used commonly are based on the opinions of experts and individuals related to a specific project [11]. Therefore, the ratings and the final result can be subject to some error that one should be aware of. Subjectivity is mainly the case in methods consisting in the consideration of the non-measurable, quality-related factors. In the case of the so-called measurable factors, assessment according to a specific criterion is obvious. To obtain an objective assessment of the quality factors two procedures are adopted. One is the descriptive assessment, and the other requires a numeric measurement scale to be adopted.

The possibility to take them into account while making a decision is ensured by various multi-criteria methods: MCE, AHP, indicator methods. However, it is difficult to estimate the error of the final results. It can be assumed that these are acceptable approximations, yet they require additional interpretation in order to make a reasonable decision $[12,13,14,15]$.

Among the methods applicable to an analysis of variants of building construction and material solutions, the ones mentioned in the paper are the most common. Traditional and relatively simple methods are score assessment or weighting methods. A similar analytical method is the MCE approach. All are based on an assessment of scores assigned for satisfying individual criteria by the analysed variants. The procedure is easy to follow, but it is not recommended when the number of criteria is high. A direct comparison of numerous criteria leads to the fragmentation of values, which in turn flattens the results and causes problems in identifying the criteria which actually play a dominant role in selecting one variant over the others $[16,17]$.

In a situation when we are to evaluate variants based on ten or more criteria, it is recommended to apply methods of hierarchical analysis, where the starting point for further analyses is to order the criteria and divide them into groups. The subsequent analysis deals with the main criteria, and then there are subcriteria comprised within each group of the main criteria. The structure of criteria should be such as to ensure that the number of main parameters should be less than ten. Having multiplied the significance of the main criteria by the assessment results of the subcriteria, we obtain the accumulated effect and more diversified results. Among the multi-criteria methods based on the hierarchical approach, noteworthy are AHP, PAHP and ANP [18, 19, 20].

In all the aforementioned methods, the starting point for further analyses is to identify the criteria and define the scale of their assessment [21]. It typically ranges from 0 to $5-10$ at the most, and zero means that a given criterion is not satisfied at all, while the highest value corresponds to its complete fulfilment. When evaluating the significance of importance, another possible approach, developed by Professor Saati, consists of making pairwise comparisons.

The method proposed by the author of this paper, called the Indicator Method, is of a completely different 
nature. This method enables the user to include negative values whenever a given evaluation parameter can cause adverse effects. In this approach, it is possible to evaluate direct and indirect effects of the performance of a given development project [22].

\subsection{Determination of criteria for variant choice}

While planning a project the investor should analyse various criteria for the evaluation of the feasible solutions $[23,24]$. It is also important to find out what features of the variants studied are most important for the structure being designed. In the case analysed, the possible assessment criteria can be related to:

1) Structural and strength characteristics of the components analysed

2) Structure lightness

3) Structure resistance to ambient conditions, including resistance to fire

4) Ease of transport and assembly

5) The cost of project completion and its later maintenance

6) Durability of the structure and its recyclability.

7) Aesthetic and architectonic factors.

The criteria analysed should be developed taking into account the nature of the method applied. Depending on the phenomenon described by the said criteria, they can be expressed in a measurable ( $\mathrm{m}, \mathrm{kg}, \mathrm{PLN})$ or nonmeasurable manner (environmental factors, architectonic and aesthetic aspects, ease of installation, etc.). A starting point for every multi-criteria analysis method is to assess the validity of the predefined criteria. This stage requires in many cases the participation of experts and the performance of properly constructed surveys [24]. There are, however, instances when the criteria can be determined and their validity verified by the investor or designer. The participation of experts is mostly due to the need to study the experience related to the solutions adopted or the expectations of the project being planned.

\subsection{Proposed analysis methods}

To give an overview of the procedure of a multicriteria analysis, first, the MCE (Multi-Criteria Evaluation), one of the simplest methods, will be described. This method relies upon the determination and estimation of the importance of criteria and their fulfilment degree by the following project variants [5, 25]. The method discussed is used to aid the decision-making process when several or more criteria are available. The first step of the MCE analysis is to define the criteria leading to the planned objective. The criteria present in the MCE analysis can be divided to two groups:

- hard criteria ( - constraint): barriers, limitations,

- $\quad$ soft criteria ( - factor): parameters, factors.

With the application of hard criteria it is possible to reject some of the variants considered, while with the soft criteria the feasibility of variants for the purpose determined in the analysis can be achieved. The result obtained with the soft criteria is not as clear as for the hard criteria. The feasibility is calculated from the formula:

$S=\sum_{i-1}^{n} w_{i} \cdot x_{i} \quad i \in\langle 1, n\rangle$

where: $S$-feasibility, $w$ - criterion importance, $x-$ parameter value, $i$ - another criterion, $n-$ number of criteria.

For an analysis in which there are also the "barrier" type criteria, the formula takes the form:

$S=\sum_{i-1}^{n} w_{i} \cdot x_{i} \prod c_{j}$

where: $c_{j}-j^{\text {th }}$ limitation.

The criteria adopted in the analysis refer to the need to meet specific conditions by a given variant. With the hard method the criteria are defined as barriers (e.g. the structure weight not greater than, girder span not less than). In the case considered, only the soft criteria will be analysed.

The method presented allows a simple and clear evaluation of the solutions. However, a more in-depth analysis is often required. There are situations in which it is recommended to analyse the sub-criteria to find out what actually, in the main criteria group, decides their higher and lower rank. In this case the methods belonging to the hierarchic analyses (e.g. AHP) are useful [18]. It is often important to determine the positive and negative effects of the project, e.g. on the social and natural setting, or to evaluate the direct and indirect consequences of the solution chosen. If this is the case, the author proposes to apply her original indicator method [26]

In the Indicator Method [22, 26] tabular matrices are used in which individual effects are described and weights are assigned to the following criteria (effect significance). The variants analysed are covered in the compilation of the information of interest. Table 3 presents the matrix construction principle.

Table 3 An example of matrix for calculations by the indicator method

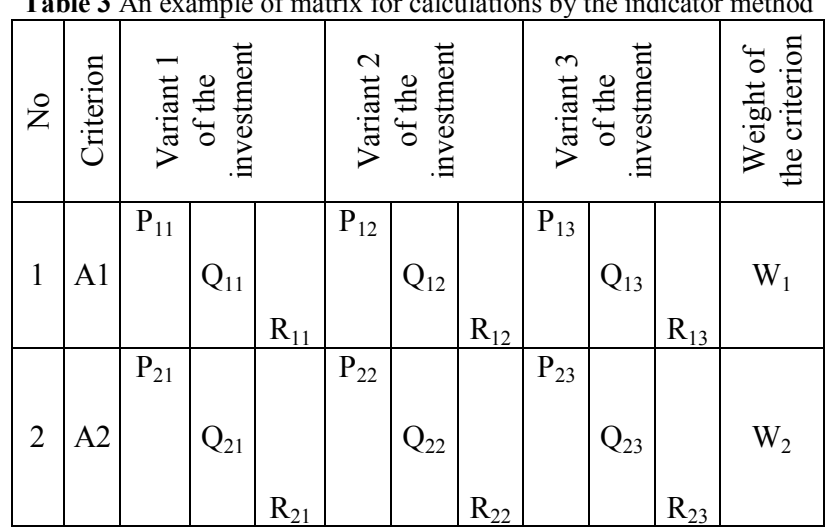

The number in the top left corner of a cell describes the direct effect, and the number in the bottom right corner describes the indirect effect in relation to the entire construction and its further use. In the middle there is the sum of effects multiplied by the weight. The sum of 
individual effects is the partial assessment of the environmental impact of a given variant.

The partial assessment on the effect of the $j^{\text {th }}$ variant on the ith criterion:

$Q_{i j}=\left(P_{i j}+R_{i j}\right) \cdot W_{i}$

where: $P_{i j}$ - direct effect of a subsequent variant in the context of criterion $\mathrm{A} ; R_{i j}$ - indirect effect of a subsequent variant in the context of criterion A; $W_{i}-$ weight of criterion A.

\section{Solution of the problem with the MCE method}

According to the procedure described above, the first step in the analysis, with any method, is to determine the criteria leading to the achievement of the objective. In the methods proposed previously there are no limitations as to the number of factors compared simultaneously, so a uniform compilation can be provided. It was determined that the following criteria of the variants analysed should be considered

1) Ease of installation

2) Structure lightness

3) Structure resistance to ambient conditions

4) Resistance to fire

5) Recyclability

The importance was determined by the investor after consulting with the contractor and users of similar structures, taking into consideration the success of the planned project. Their values are within the range $0-1$.

The values of parameters were determined based on the opinions of experts, designers and the investor. A 0-6 scale was adopted, where 0 means the failure to meet a given criterion, and 6 means meeting it to the maximum degree. A scale from 0 to 6 was adopted for the evaluation of all criteria:

0 - complete lack of fulfilment of a criterion

1 - poor fulfilment of a criterion

2 - satisfactory fulfilment of a criterion

3- good fulfilment of a criterion

4 - high fulfilment of a criterion

5 - very high fulfilment of a criterion

6 - maximum fulfilment of a criterion

Depending on the character of a criterion, the scale is applied to values originating, for example, from the building plan documentation, e.g. light-weight structure, costs, and other measurable criteria, or else a descriptive assessment scale is used for evaluating less measurable parameters. For example, a descriptive scale for 'ease of assembly works':

0 - extremely difficult assembly works, requires hiring extra staff with unique qualifications and specialist equipment, consumes much time and labour, often practically impossible in certain circumstances;

1 - very difficult assembly works, requires hiring specialist staff with specialist equipment, highly time consuming, possible to accomplish in specific circumstances, but needs additional time to be performed;
3 - moderately difficult assembly, at some stages it is necessary to have higher specialist staff supervising the work done with specialist equipment;

4 - relatively simple assembly, possible to conduct with own workforce and equipment, but requires consultations with experts, who ensure that the work is done efficiently; consultations take some time;

5 - simple assembly, possible to conduct with the workforce and equipment of a building company which completes the whole building investment project, the assembly work runs smoothly, with minor complications which do not affect the time needed to perform the task; 6 - very simple assembly, possible to conduct with the workforce and equipment of the construction company which carries out the whole project; the work runs smoothly with no complications.

Scales for the assessment of the other criteria can be described likewise. The calculations are listed in Tab. 4.

Table 4 Multi-criteria evaluation for analysed variants

\begin{tabular}{|c|c|c|c|c|c|}
\hline 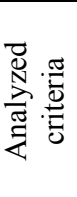 & 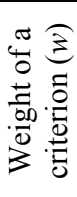 & 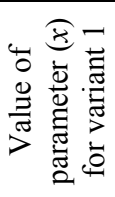 & 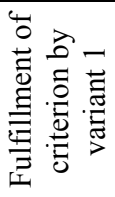 & 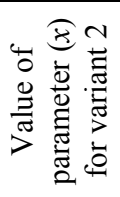 & 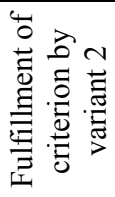 \\
\hline 1 & 0,10 & 4 & 0,40 & 5 & 0,50 \\
\hline 2 & 0,25 & 3 & 0,75 & 4 & 1,00 \\
\hline 3 & 0,35 & 5 & 1,75 & 2 & 0,70 \\
\hline 4 & 0,20 & 4 & 0,80 & 2 & 0,40 \\
\hline 5 & 0,10 & 2 & 0,20 & 6 & 0,60 \\
\hline sum & 1,00 & & 3,90 & & 3,20 \\
\hline
\end{tabular}

Tab. 4 provides information on whether the partial criteria are satisfied and, in the summary, the result deciding which variant meets the criteria analysed to the highest degree. According to the analysis performed, the pre-stressed concrete structure is a better solution in the case in question. This is mainly due to its high resistance to ambient conditions, and the fire resistance of the structure.

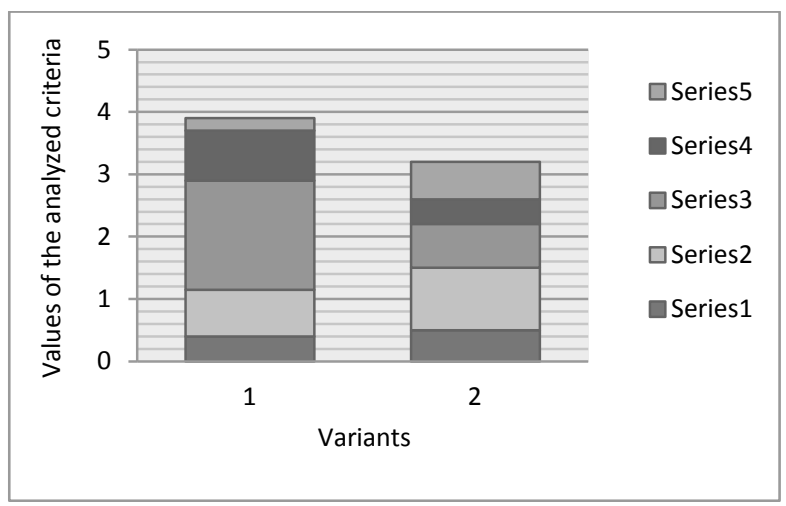

Figure1 Graphic interpretation of results obtained with MCE

The graphic interpretation (Fig.1) shows the structure share of individual criteria, and makes it possible to view the ultimate result of the analysis.

\section{Solution of the problem with the Indicator Method}

Similarly, as in the previous method, the Indicator Method (IM) included surveys and interviews with 
experts. The expert assessments were analysed and, after rejecting the extremes, the average assessment of the direct and indirect effects was achieved. The scale used in the IM approach refers to an assessment of the direct and indirect impact of a given variant in the evaluation of the analyzed variants. Direct effects of a solution are evaluated on a micro-scale - regarding the structure per se, while indirect effects are viewed in a broader context, concerning future users or the macro-environment.

It was also necessary to determine the importance of the criteria provided earlier. The importance defines the priorities which, to various degrees, can fulfil the variants designed, and were not changed due to analysis of the same problem. The calculations are listed in Tab.5.

Table 5 Matrix for calculations according to the indicator method

\begin{tabular}{|c|c|c|c|c|c|c|c|c|}
\hline$\stackrel{\circ}{Z}$ & 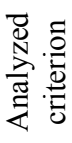 & \multicolumn{3}{|c|}{ 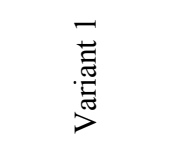 } & \multicolumn{3}{|c|}{$\stackrel{\substack{\stackrel{D}{\Xi} \\
\stackrel{\Xi}{*}}}{>}$} & 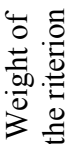 \\
\hline 1 & A1 & 3 & 0,40 & 1 & 5 & 0,80 & 3 & 0,10 \\
\hline 2 & $\mathrm{~A} 2$ & 3 & 1,75 & 4 & 4 & 2,25 & 5 & 0,25 \\
\hline 3 & A3 & 5 & 3,15 & 4 & 4 & 2,24 & 3 & 0,35 \\
\hline 4 & A4 & 3 & 1,6 & 5 & 4 & 1,00 & 1 & 0,20 \\
\hline 5 & A5 & 2 & 0,50 & 3 & 4 & 0,70 & 3 & 0,10 \\
\hline & sum & & 7,40 & & & 6,99 & & 1,00 \\
\hline
\end{tabular}

The values shown in table 4 are estimated through a comparison of the analyzed solutions. An example is the light weight of a structure, where the steel construction is lighter and scored higher than the prestressed concrete structure in direct assessment. The same is true about the indirect evaluation, where a lighter structure generates fewer problems while being transported to the construction site, which is considered to belong to indirect effects. The remaining criteria are analyzed in a similar fashion.

The calculations can be presented in the form of graphs showing the accumulated effect of the distribution analysis (series 5) of the values provided in the table (Figs. 1 and 2). The trend of every value portion in time can be seen in the graphs. The middle value on those charts is updated by multiplying by the importance assigned to the following criteria. The comparison of the end results of the analysis, shown in graphs in Figs. 2 and 3 , presents the advantage of variant 1 over variant 2 . This can be read from the line corresponding to series 5 in the value description.

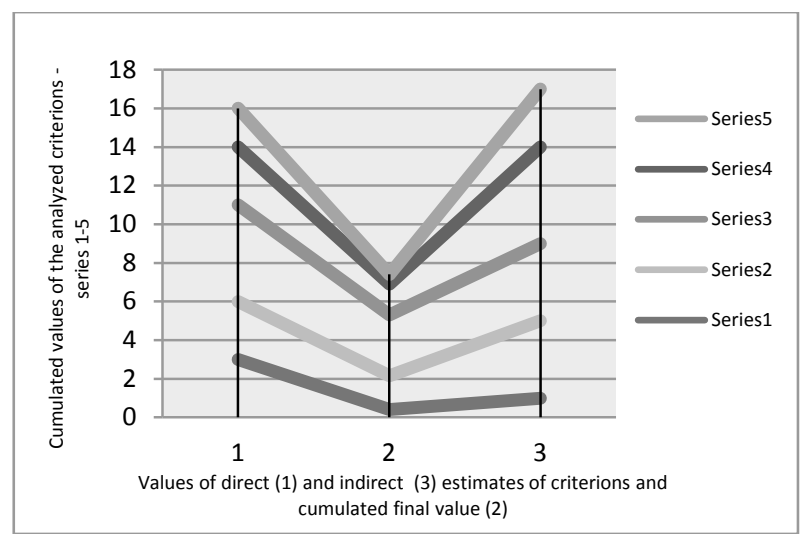

Figure 2 Distribution of the analysed values for the variant I

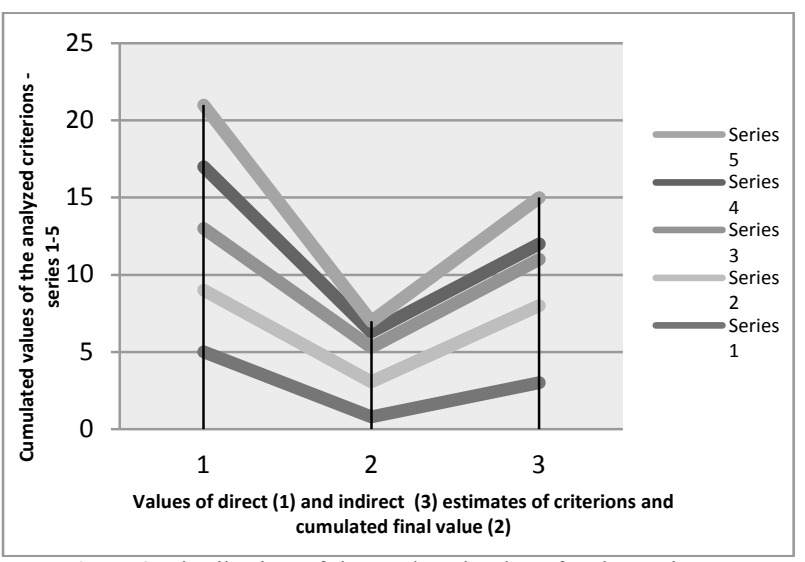

Figure3 Distribution of the analysed values for the variant II

After analysis the results obtained provide answers to many questions about the choice of variants of the planned project. Detailed analysis of the direct and indirect effects proves that criteria 2 and 3 are most important for the planned project (which can be assessed based on the distance between those lines on the charts), and the resistance to ambient conditions is critical for the advantage of variant one over variant two. It should be emphasised that in the Indicator Method negative values can also be considered, which reflect the negative effects of some criteria in the category.

In the process of construction project preparation the development and analysis of various solution variants is of key importance. One of the problems the designer has to solve in agreement with the investor is the choice of structural materials and solutions. The technologies available should be analysed with the use of methods supporting the decision-making process. The procedure presented can be successfully applied to analyse the measurable and non-measurable criteria. One of the multicriteria methods is the Indicator Method presented in the paper and compared to the MCE method.

\section{Summary and analysis of the results obtained}

In the process of construction project preparation the development and analysis of various solution variants is of key importance. One of the problems the designer has to solve in agreement with the investor is the choice of structural materials and solutions. The technologies available should be analysed with the use of methods supporting the decision-making process. The procedure presented can be successfully applied to analyse the measurable and non-measurable criteria. One of the multicriteria methods is the Indicator Method presented in the paper and compared to the MCE method.

This method differs from others in that it allows taking into account the direct and indirect consequences of the project and its negative effects to a greater degree than the other methods. Despite the complexity involved in data preparation, it is extremely useful in such analyses. The main advantages of the Indicator Method include the possibility to analyse the variants studied in detail, and to take into account a broader scale in the assessment of results. A very interesting point of the 
analysis is the assessment of the direct and indirect effects of the variant analyses on the ultimate project, environment or execution conditions, and its operation later on. This characteristic is typical for this method only, and is very important in many cases. As a result, it provides an answer to the question of which components are critical for the positive or negative final assessment of the project variant.

The fragment of the comparative analysis presented demonstrates the feasibility of multi-criteria methods for the assessment of various solution variants, and underlines the importance of such analyses in investment practice in the building industry, and the example presented emphasises the usefulness of the Indicator Method.

\section{$7 \quad$ References}

[1] Szafranko, E. Methods of comparison steel and reinforced concrete structure's on example of a one-storey, single-span frame. // Journal of International Scientific Publications: Materials, Methods \& Technologies. 7(2014), pp. 328-339.

[2] Morris, P. W. G Lessons in managing major projects successfully in a European context. // Technology in Society. 10, 1(1988), pp. 71-98. https://doi.org/10.1016/0160-791X(88)90026-7

[3] Yang, L.-R.; Chen, J.-H.; Wang, H.-W. Assessing impacts of information technology on project success through knowledge management practice. // Automation in Construction. 22, (2012), pp. 182-191. https://doi.org/10.1016/j.autcon.2011.06.016

[4] Šelih, J.; Kne, A.; Srdić, A.; Žura, M. Multiple-criteria decision support system in highway infrastructure management. // Transport. 23, 4(2008), pp. 299-305. https://doi.org/10.3846/1648-4142.2008.23.299-305

[5] Szafranko, E. Multi-criteria methods in an analysis of variants of a construction project. // Journal of International Scientific Publications: Materials, Methods \& Technologies. 9(2015), pp. 155-168.

[6] Saric, T.; Simunovic, K.; Pezer, D., Simunovic, G. Inventory classification using multi-criteria $a b c$ analysis, neural networks and cluster analysis. // Technical Gazette. 21, 5(2014), pp. 1109-1115.

[7] Madić, M.; Radovanović, M.; Petković, D.; Nedić, B. Multi-Criteria Analysis of Laser Cut Surface Characteristics in $\mathrm{CO}_{2}$ Laser Cutting of Stainless Steel. // Tribology in Industry. 37, 2(2015), pp. 236-243.

[8] Navon, R. Research In automated measurement of project performance indicators. // Automation in Construction. 16, 2(2007), pp. 176-188. https://doi.org/10.1016/j.autcon.2006.03.003

[9] Rouyendegh, B. D.; Bac, U.; Erkan, T. E. Sector selection for ERP implementation to achieve most impact on supply chain performance by using AHP - topsis hybryd method. // Technical Gazzette. 21, 5(2014), pp. 933-937.

[10] Klimenko, E. V.; Korol, N. D.; Korol, I. V.; Kos, Ž. Predicting the durability of the columns on the criterion of concrete carbonation and corrosion of reinforcement. // Tehnički glasnik. 9, 3(2015), pp. 317-320

[11] Naveh, E.; Marcus, A. Achieving competitive advantage through implementing are applicable management standard: installing andusing ISO 9000. // Journal of Operations Management. 24, 1(2005), pp. 1-26. https://doi.org/10.1016/j.jom.2005.01.004

[12] Abu Dabous, S.; Alkass, S. Decision support method for multi-criteria selection of bridge rehabilitation strategy. // Construction Management and Economics. 26, 8(2008), pp. 883-893. https://doi.org/10.1080/01446190802071190
[13] Brown, M. A. Construction management: the management of the development, conservation and improvement of the built environment. // Organization, Technology \& Management in Construction: An international Journal. 4, 2(2012), pp. 457-460. https://doi.org/10.5592/otmcj.2012.2.1

[14] Marques, G.; Gourc, D.; Lauras, M. Multi-criteria performance analysis for decision making In Project management. // International Journal of Project Management. 29, 8(2011), pp. 1057-1069. https://doi.org/10.1016/j.jproman.2010.10.002

[15] Negahban, S. S.; Baecher, G. B.; Skibniewski, M. J. A decision- making model for adoption of enterprise resource planning tools by small -to -medium size construction organizations. // Journal of Civil Engineering and Management 8, 2(2012), pp. 253-264. https://doi.org/10.3846/13923730.2012.666503

[16] Zavadskas, E. K.; Kaklauskas, A.; Peldschus, F.; Turskis, Z. Multi-attribute assessment of road design solutions by using the COPRAS method. // The Baltic Journal of Road and Bridge Engineering. 2, 4(2007), pp. 195-203.

Chen RH, Lin Y, Tseng ML. Multicriteria analysis of sustainable development indicators in the construction minerals industry in China. // Resources Policy. 46, (2015), pp. 123-133. https://doi.org/10.1016/j.resourpol.2014.10.012

[17] Saaty, T. L. Fundamentals of decision making and priority theory with the analytic hierarchy process, McGraw Hill Publishers, New York, 2000.

[18] Özdağoğlu, A.; Güler, M. E. E-service quality of internet based banking using combined fuzzy AHP and fuzzy TOPSIS. // Technical Gazette. 23, 4(2016), pp. 1109-1116.

[19] Saaty, Thomas, L. Decision making - the analytic hierarchy and network processes (AHP/ANP). // Journal of systems science and systems engineering. 13, 1(2004), pp. 1-35. https://doi.org/10.1007/s11518-006-0151-5

[20] Szafranko, E. Ways to determine criteria in multi-criteria methods applied to assessment of variants of a planned building investment. // Technical Transactions, ISSUE 2-B (6), 2014(111), pp. 41-48.

[21] Szafranko, E. Applicability of the indicator method to evaluation of road building projects. // News in Engineering 1/2015, pp. 1-7.

[22] Triantaphyllou, Es. Multi-criteria decision making methods: a comparative study. Vol. 44. Springer Science \& Business Media, 2013.

[23] Tunjic, D.; Kljajin, M.; Kondic, V. Research and ranking of the factors of impact on efficiency and effectiveness of the quality management system certification process using the prior factor ranking method. // Technical Gazette. 21, 5(2014), pp. 383-388.

[24] Yoon, K.; Hwang, C. Multiple Attribute Decision Making: An introduction, Sage Publications, London, 1995. https://doi.org/10.4135/9781412985161

[25] Szafranko, E. Applicability of the indicator method to evaluation of the impact of road building projects on the natural environment. // 3rd Electronic International Interdisciplinary Conference EIIC 2014, 1-5 September, 2014, pp. 519-523.

\section{Author's addressee}

Elżbieta Szafranko, PhD, Assistant Prof

University of Warmia and Mazury in Olsztyn, Faculty of Geodesy, Geospatial and Civil Engineering, ul. Heweliusza 4, 10-724 Olsztyn, Poland E-mail: elasz@uwm.edu.pl 